\title{
Landskap van gemeentesang in die Nederduitse Gereformeerde Kerk aan die begin van die een-en-twintigste eeu: Voorlopige verkenning
}

\author{
Author: \\ Coenie Calitz \\ Affiliation: \\ ${ }^{1}$ Faculty of Theology, \\ North-West University, \\ Potchefstroom Campus, \\ South Africa \\ Correspondence to: \\ Coenie Calitz \\ Email: \\ cjcalitz@lantic.net \\ Postal address: \\ PO Box 5539, Kockspark \\ 2523, South Africa

\section{Dates:} \\ Received: 21 Jan. 2014 \\ Accepted: 12 Sept. 2014 \\ Published: 19 Mar. 2015 \\ How to cite this article: \\ Calitz, C., 2015, 'Landskap \\ van gemeentesang in die \\ Nederduitse Gereformeerde \\ Kerk aan die begin van \\ die een-en-twintigste eeu: \\ Voorlopige verkenning', In \\ die Skriflig 49(1), Art. \#1795, \\ 11 pages. http://dx.doi. \\ org/10.4102/ids.v49i1.1795

\section{Copyright:} \\ (C) 2015. The Authors. \\ Licensee: AOSIS \\ OpenJournals. This work is \\ licensed under the Creative \\ Commons Attribution \\ License.
}

Read online:
Musiek en sang binne die Nederduitse Gereformeerde Kerk (NG Kerk) is in 'n proses van radikale verandering. Binne 'n 'global village' kan die ses strominge van kerkmusiek soos Paul Basden (2004) dit beskryf het, van groot waarde wees om die huidige prosesse in die NG Kerk te identifiseer en te beskryf. Hierdie prosesse word dikwels oorvereenvoudig deur die gebruik van die term 'blended worship'. 'n Dieper kyk na die bedoeling en betekenis van die term 'blended worship' wys dat die term in baie gevalle nie vir die huidige situasie of prosesse in die NG Kerk geskik is nie. Die huidige situasie veronderstel nie net die gebruik van nuwe vorms van musiek naas die oue nie, maar in baie gemeentes impliseer dit 'n wegbeweeg van die oue na die nuwe. Die uitdaging bly steeds om binne hierdie situasie getrou aan die Woord van God te bly, maar ook om effektief na die behoefte van die mense van ons tyd te handel.

Landscape of congregational singing in the Dutch Reformed Church at the beginning of the 21th century: Preliminary exploration. Music and singing in the Dutch Reformed Church (DRC) is in a process of radical change. Within a global village, the six views of worship as identified by Paul Basden (2004) could be of great value in understanding die processes and streams within the music of the DRC. Variations and combinations of these views (streams) could be observed within the present-day liturgical singing within the DRC. This process is often oversimplified by using the term blended worship; a closer look at blended worship illustrates that the term blended worship in its original intention does not fit the current situation or process. The current situation does not only imply new forms of music combined with the old forms, it often implies a move away from the old in the direction of the new. Within this process the challenge of the DRC will be to stay faithful to the Word of God as well as contemporary society.

\section{Inleiding}

Vir honderde jare was die sang en musiek in die Nederduitse Gereformeerde Kerk (hierna NG Kerk) grootliks voorspelbaar: dieselfde repertorium, aanbieding en styl kon in alle gemeentes van die NG Kerk waargeneem word en dit is eenvoudig as gereformeerde sang beskryf. In die afgelope eeu is die repertorium saamgevat en in gedrukte vorm beskikbaar gestel via die Psalmberyming (1937), die Gesangebundel (1944), die Psalms en Gesange (1978) en die Liedboek van die Kerk (2001) (Du Toit 1983). Die begeleiding is deur die kerkorrel verskaf met 'n min of meer voorspelbare ritme en inkleding (vgl. Strydom 1983:192-193).

In die afgelope aantal jare (25 jaar?) het hierdie prentjie egter dramaties verander. Sang en musiek verskil vandag van gemeente tot gemeente binne dieselfde denominasie (NG Kerk) en is grootliks onvoorspelbaar. Die repertorium het in baie gemeentes verbreed na 'n onbeperkte aantal liedere uit 'n onbeperkte aantal bronne, tydvakke, tradisies en genres. Die begeleiding is nie meer per se die van die kerkorrel nie en die begeleier of musikant is nie noodwendig 'n orrelis nie. Terme soos aanbiddingsleier, worship leader, musiekgroep, orkes, band, en nog meer het algemene begrippe binne baie gemeentes geword. Dikwels word verskillende eredienste vir verskillende groepe binne die kerk gehou. In baie gevalle lê die enigste of grootste verskil tussen die verskillende eredienste in die sang en musiek: die repertorium, begeleiding, musikant(e), style, genres, of kombinasies daarvan (Calitz 2011:2). Met betrekking tot die liturgie hoor 'n mens al hoe meer die term bricolage $^{1}$ (vgl. Barnard 2008). Hierdie term word al hoe meer ook met betrekking tot musiek en sang in die erediens gebruik (vgl. Hoondert 2009). Binne die konteks van sang en musiek

1.Bricolage verwys na die gebruik van bricoleurs om instrumente bymekaar te maak wat hulle later kan gebruik, sonder om op daardie oomblik te weet wat hulle daarmee gaan doen. Bricolage binne die liturgie lei tot ' $n$ soort knip- en plakwerk waar hulpmiddels uit verskeie tradisies en agtergronde deur die bricoleur saamgevoeg word (vgl. Barnard 2008:14-16; Hoondert 2009). 
hoor 'n mens ook al hoe meer die term 'blended worship' en 'convergence music' (Van der Merwe 2009b:251-252). Hierdie proses van verandering word met verskillende sentimente en emosies deur verskillende rolspelers en deelnemers beoordeel.

Hierdie artikel is slegs 'n voorlopige verkennende studie en poog om die verskuiwings en bewegings met betrekking tot gemeentesang in die NG Kerk te identifiseer en daarmee saam moontlike implikasies vir die breër gereformeerde kerk aan te dui. Die vertrekpunt is dat die verskuiwings binne die musiek van die NG Kerk nie beperk is tot die NG Kerk of Suid-Afrika nie. Die vraag is watter benaderings tot gemeentesang en -musiek vandag waarneembaar is, watter verskuiwings besig is om plaas te vind, en watter uitdagings dit vir die plaaslike (gereformeerde) gemeentes inhou.

Eerstens word kortliks na die ses groot benaderings tot gemeentesang gekyk soos Paul Basden (2004) dit identifiseer, beskryf en beoordeel. Vervolgens word aan die hand van enkele liturgiese variasies op hierdie groot benaderings geillustreer wat in gemeentesang en -musiek binne die NG Kerk (en waarskynlik ook in ander gereformeerde kerke) neerslag vind. Laastens word gepoog om hierdie proses te beskryf.

Die volgende afkortings of simbole word deurgaans in die artikel gebruik:

FLA: Formeel-liturgiese aanbidding (Formal liturgical worship').

TLGA: Tradisionele liedboekgebaseerde aanbidding (Traditional hymn-based worship).

KA: Kontemporêre aanbidding (Contemporary worship).

CA: Charismatiese aanbidding (Charismatic worship).

GA: Gemengde aanbidding (Blended worship).

OA: Opkomende of ontluikende aanbidding (Emerging worship).

\section{Ses benaderings tot die erediens (gemeentesang)}

Basden (2004) identifiseer ses prominente bewegings in of benaderings tot die erediens (dus ook kerksang en-musiek) in Noord-Amerika. Basden se publikasie is uniek daarin dat die verskillende benaderings tot die erediens opgesom en beskryf word deur kenners van die betrokke aanbiddingstyle ${ }^{2}$ self; dus 'n beskrywing en waardering van binne. Calitz (2011) dui aan dat musiekstyle en -genres nie van buite beoordeel kan word nie, aangesien alle vorms van kerkmusiek en -sang ten nouste met die kultuur van die denominasie of die plaaslike gemeente verbind is; musiek

2.Die woord, aanbiddingstyl, is uit die Praise-and-Worship-beweging afkomstig en is nie ' $n$ goeie beskrywing vir die omvattende aard van gemeentesang nie gemeentesang is meer as net lof of net aanbidding. is deel van die gemeente se kleinverhaal. Die publikasie is verder uniek daarin dat die verteenwoordigers van die verskillende benaderings tot die erediens met mekaar in gesprek tree oor die erediens (asook die musiek binne die erediens) en daar dus ook 'n waardevolle waardering en evaluasie van buite plaasvind. Hierdie gesprek is wesenlik belangrik in die ontlonting van die voortgaande 'worship wars' (vgl. Long 2001:1) en in die soeke na oplossings vir die dilemma waarin die gereformeerde kerke hulself met betrekking tot die kerklied bevind. 'n Eensydige waardering en evaluering van buite deur slegs een benadering tot die kerklied bied weinig waarde.

Basden (2004) se ses benaderings tot aanbidding (die erediens) sou goedskiks gesien kon word as 'n meer gedetailleerde beskrywing van die drie kragte waarvan Long (2001) melding gemaak het. ${ }^{3}$ 'n Baie kursoriese opsomming van elkeen van hierdie benaderings word aangebied, asook die moontlike waardes en leemtes van elke benadering soos dit in die interaksie tussen voorstanders van die verskillende benaderings duidelik word. Elke soort musiek binne die erediens kan slegs verstaan word binne die groter prentjie van die erediens (liturgie) waarbinne dit funksioneer. 'n Beskrywing van sang en musiek noodsaak daarom ook 'n kort beskrywing van die liturgie. So 'n beskrywing is altyd onvolledig omdat liturgie meer is as net die opeenvolging en vloei van bepaalde elemente. Die belewenis en atmosfeer binne die erediens asook die werking van die Heilige Gees in deelnemers se harte tydens die erediens kan ongelukkig nie hier beskryf en verreken word nie.

\section{Formeel-liturgiese aanbidding ${ }^{4}$ (Formal liturgical worship)}

Zahl(2004:21-36) beskryf die formeel-liturgiese erediens (FLA van hier af) as 'n erediens (en dus ook musiek) met 'n bybelse vertikaliteit (gerig op God). Die musiek kan moeilik verstaan word buite die liturgiese raamwerk waarin dit funksioneer. Dit het 'n vaste vorm en laat weinig ruimte vir spontaniteit. Dit is voorgeskrewe musiek en word grootliks deur die plek binne die liturgie bepaal. Dit het ' $n$ meer formele karakter en is by uitstek liturgiese musiek. FLA is Skrifgesentreerd en Zahl (2004:24) beklemtoon dat dit nie prediker-georiënteerd is nie. Dit berus baie sterk op die beginsel van Lex Credendi Lex Orandi - wat ons glo die bepalende is van hoe ons (aan) bid. FLA is op die Sola Scriptura-beginsel van die Reformasie gebou met die klem op '(r)ight (Bible) thoughts of God, right (Bible) thoughts of Christ, right (Bible) thoughts of the human being' (Zahl 2004:26). Binne die formeel-liturgiese beweging het die nagmaal 'n sentrale plek. Musiek vervul verskeie Hippolytus Force dieryf hierdie verskynsel as ' $n$ konflik tussen drie kragte, naamlik die na die herontdekking van die reek Force en die Third Way. Hippollytus Force verwys na die invloed van die Liturgiese Vernuwingsbeweging. Die Willow Creek Force dui grootliks op die invloed van megakerke soos Willow Creek (en hulle soekergeoriënteerde aanbidding) op gemeentesang. Third Way sou beskryf kon word as 'n derde opsie nas die Hippolytus en Willow Creek Forces - die opsie waarvoo Long (2001) pleit.

4.Die term worship kan onder andere na die element van aanbidding of na die totale erediens verwys waar aanbidding net een element in die erediens is. Die term word ook dikwels gebruik as ' $n$ verkorte vorm vir die term praise and worship. In hierdie artikel word die term worship (soos deur Basden gebruik) vertaal met aanbidding of artikel word die term worship (soos deur Basden gebruik) vertaal met aanbidding of
erediens, maardit dui meer spesifiek op die sang binne die erediens. 
funksies binne die formeel-liturgiese beweging. Eerstens dien dit as katalisator vir menslike emosies, naamlik as 'sighs too deep for words' (Rom 8:26). Tweedens het dit 'n lerende funksie deurdat dit tot geestelike verdieping en geestelike opbou bydra. Musiek in FLA is meesal 'music of quality married to words of substance' (Zahl 2004:29) waar 'music of quality' primêr op musiek uit die westerse Christelike kanon dui. Zahl (2004:30-33) dui tereg self drie besware teen FLA aan, naamlik dat dit die werking van die Heilige Gees beperk (quench), dat dit dikwels koud en klinies is, en dat dit nie gebruikersvriendelik is nie (veral ten opsigte van buitestanders en dus ten opsigte van evangelisasie).

Kritiek vanuit die ander vyf benaderings (Basden 2004: 37-55) tot hierdie erediensbenadering sluit onder andere in die oorbeklemtoning van die vertikale dimensie en die onderbeklemtoning van die horisontale dimensie, voorspelbaarheid (vaste orde), wêreldvreemdheid, beperking van die werking van die Heilige Gees, ontkenning van die postmoderne mens en die wêreld, die afwesigheid van nuwe en moderne style soos Kelties, blues, urban, en so meer.

\section{Tradisionele liedboekgebaseerde aanbidding (Traditional hymn-based worship)}

Best (2004:59) beskryf die tradisionele liedgebaseerde aanbidding (TLGA) as aanbidding wat op die uitgangspunt rus dat ons nie geskep is om te aanbid nie, maar dat ons aanbiddend (worshiping) geskep is. TLGA sluit gesonge teks (lirieke) en instrumentele musiek in. Dit bevat instruksionele en responsoriese sinne wat gesê of gesing kan word, asook geselekteerde Skrifgedeeltes. Dit sluit grootliks drie soorte gebede in, naamlik kort bedes (invocations, petitions, of benedictions), gemeentelike gebedeen pastorale gebede (namens die gemeente). Daar is normaalweg ook 'n preek - dikwels in die vorm van 'n homilie. Binne die liturgie is daar ruimte vir offergawes asook periodieke vierings van die nagmaal; laasgenoemde het meestal 'n eie, unieke kombinasie van musiek, teks en gebede. Met betrekking tot die musiek binne die TLGA meld Best (2004:64) dat liedboeke 'n belangrike rol speel en dat liedere meestal in gedrukte vorm gebruik word. Binne hierdie korpus van liedere is daar 'n sterk verbintenis tussen musiek en artefakte. Saam met die Bybel en opsionele gebedeboeke of liturgieboeke vorm die liedboek (hymnal) die primêre bron vir gemeentesang. Best (2004:65-71) noem die volgende eienskappe van die liedbundel binne hierdie stroom:

- Dit is ' $n$ tydelike en mensgemaakte dienskneg van die Woord.

- Dit is 'n boek met 'n diversiteit van style.

- Dit bevat tekste en musiek van hoogstaande gehalte.

- Dit floreer op beskikbare gedrukte materiaal.

- Dit druk die geskiedkundige stryd uit om nie-bybelse tekste te sing.

- Dit is 'n uitstekende instrument vir persoonlike toewyding.

- Dit is 'n uitstekende wetenskaplike en musikale bron.

Kritiek vanuit die ander vyf benaderings teen die TLGA (Basden 2004:76-94) sluit onder andere die volgende in: selfvoldaanheid met min ruimte vir die werking van die
Heilige Gees; geneigdheid om te vergeet dat die Heilige Gees steeds mense inspireer om liedere te skryf; die fokus op mense wat reeds in die kerk is en ' $n$ mindere fokus op buitestanders; dit weerspieël dikwels ' $n$ ou vergange kultuur; die afwesigheid van elemente van die kontemporêre kultuur soos die digitale kuns, video, fotografie, populêre musiek, ensovoorts.

\section{Kontemporêre aanbidding (Contemporary worship)}

Horness (2004:99-116), 'n 'worship leader' van Willow Creek Community Church, beskryf kontemporêre aanbidding (KA) as aanbidding wat gebou is op dié God wat begeer om in 'n verhouding met die mens te staan. Hy begeer harte wat Hom ken. Kontemporêre musiek is daarom gebore uit 'n intense begeerte om van 'disinterested reciting of creeds and singing of hymns' (Horness 2004:102) na 'n outentieke tyd van intieme interaksie met God te beweeg. Daarom maak musiek in die KA gebruik van moderne instrumente (soos kitare, tromme, sintetiseerders, perkussie en horings) en kontemporêre musiekstyle (soos rock, jazz, hip-hop, rap, gospel, ens.). Nuutgekomponeerde asook nuut-gerangskikte ${ }^{5}$ liedere (nuwe verwerkings van ou liedere [hymns]) binne die taal en idioom van die huidige generasie is belangrik (Horness 2004:102). Hierdie vorms van musiek word dikwels met ander kreatiewe elemente soos Skrif, gebede, liturgiese elemente en visuele voorstellings gekombineer. Op die oppervlak word musiek in KA dikwels met tromme, kitare, refreine, dataprojektors, 'n worship team (met mikrofone) en 'n worship leader geassosieer. Die klem in KA val egter nie net op die instrumente en die genres van musiek nie, maar veral op die begeerte om God outentiek te aanbid. Ervaring speel 'n groot rol in die KA-beweging. Die strewe van KA is ' $n$ verhouding met God; hierin speel tweerigtingkommunikasie tussen God en die mens 'n groot rol. KA het ten doel 'to produce authentic worshipers of Jesus Christ' ${ }^{6}$ (Horness 2004:109). Binne die KAbeweging word van die standpunt uitgegaan dat die orrel nie ' $n$ appèl tot moderne generasies en jonger mense maak nie (Horness 2004:105). KA sluit by die kultuur van die dag aan en maak dit makliker vir buitestanders om in te kom. Horness (2004:110) meen dat KA nie verbruikersgeoriënteerd is nie, maar in die hart van God ontstaan. Die 'contemporary worship leader' speel 'n belangrike rol in die liturgie van die KA-beweging en skep die geleentheid vir deelnemers om God te ontmoet. Musiek binne die KA-beweging is ' $n$ offer en vereis elke deelnemer se beste (Horness 2004:115).

Voorstanders van die ander vyf benaderings opper tereg die volgende kritiek teen die KA-beweging (Basden 2004:117-136): KA maak dikwels verkeerdelik aanspraak daarop dat dit die enigste musiek is wat tot ' $n$ ontmoeting met en ' $n$ belewenis van God lei; dit kom dikwels werksgedrewe voor in plaas van geloofsgedrewe; die persepsie word geskep dat KA noodwendig tot'n ontmoeting met God lei (die styl van aanbidding bemiddel

5.Seleksies uit liedere word geneem (bv. verse, refreine of versreëls) en nuut gerangskik om'n nuwe lied of keurspel te vorm.

6. Horness (2004:110) beskryf outentieke aanbidders van Jesus Christus as mense wat sensitief is vir sy stem, gehoorsaam is aan sy wil, getrou bid, uitreik en lewens leef wat uitdrukking aan hulle aanbidding (worship) gee. 
of veroorsaak dus die ontmoeting); die (foutiewe) aanname dat die orrel nie ook mense in die moderne konteks kan aanraak nie; asook 'n persepsie van 'n tekort aan artistieke diepte in KA Verder neig KA dikwels tot oppervlakkigheid en is daar steeds min ruimte vir ander style soos jazz. Gevoel word dikwels die maatstaf vir aanbidding. Die persepsie word soms geskep dat die worship leader en die worship team in staat is om God voluit lief te hê en voluit te aanbid; die herkenning van die gebrokenheid van die mens (ook in hulle aanbidding) is dikwels afwesig. Morgenthaler (2004:134) wys daarop dat kontemporêr dikwels nie so kontemporêr is nie, maar tot die musiek van die tagtigerjare van die vorige eeu beperk is.

\section{Charismatiese aanbidding (Charismatic worship)}

Williams (2004:139) beskryf charismatiese aanbidding (CA) as aanbidding wat uit die politieke en kulturele krisis van die sestigerjare in die VSA gebore is. CA kan teologies gedefinieer word as 'worship where the leadership and gifts of the Spirit (charismata) are evidenced and welcomed in personal and corporate praise, responding to a mighty act of God' (Williams 2004:139). CA is uit die Amerikaanse Pentekostalisme gebore. Laasgenoemde het uit die Azusa Street herlewing in 1906 ontstaan en groot klem is op die doop met die Heilige Gees gelê wat uiting in glossolalie en 'n ervaring van die Heilige Gees gevind het. Williams beskryf die Pentekostalisme as 'evangelical in its theology and revivalist in its worship' (2004:140). Pentekostalisme het in 1960 in die Episkopaalse kerk ingang gevind en in 1967 neerslag in die Rooms-Katolieke Kerk gevind. Die kontrakulture van die sestiger jare en die ontstaan van nuwe genres van musiek binne hierdie kontra-kulture het via die Jesusbeweging bygedra tot nuwe vorms van musiek (dikwels genoem Jesus music). Hierdie beweging is deur 'n sterk apokaliptiese verwagting,'n groot ywer vir evangelisasie en ook 'n baie eenvoudige en onkritiese geloof gekenmerk. Die CA-beweging is verder deur die Third Wave gevorm waar glossolalie nie meer so belangrik was nie. John Wimber speel 'n belangrike rol in hierdie beweging en beklemtoon dat aanbidding (sang) nie 'n middel tot ' $n$ doel is nie, maar 'n doel op sigself. Wimber ontwikkel 'n vyffase model vir aanbidding met die doel om intimiteit met God te ervaar. Dit sluit die volgende elemente in: Oproep tot aanbidding (call to worship), betrokkenheid (engagement), verhoging (exaltation), bewondering (adoration) en intimiteit (intimacy) (Williams 2004:143). Deur middel van CA is die plek van die Heilige Gees in die erediens herstel. CA is nie mens- of emosiegesentreerd nie, maar Godgesentreerd (trinitaries). Die gemeente is aktief in CA betrokke en die musiek het 'n transformerende effek. Williams (2004) beskryf musiek in CA (soos die musiek van Matt Redman) van binne as:

God-centered worship with spiritual depth, poetic power, and contemporary relevance

... scriptural, revealing the tensions of the biblical revelation of God - transcendent and immanent, holy and loving, inviting us into the paradox of friendship and fear. (p. 147)

Kenmerke van CA sluit die opheffing van hande, die sing in die Gees, die ontvangs van geestelike gawes, die fisiese manifestasies van die Gees se krag asook gebedsbediening in die tweede deel van die erediens in. Williams (2004:149152) noem dat kritici van CA dit dikwels as musiek met ' $n$ gebrek aan teologiese diepte sien, maar met 'n oordrewe subjektiwiteit en 'n oordrewe sentimentaliteit.

Kritiek vanuit die ander vyf benaderings tot aanbidding (eredienste en musiek) (Basden 2004:153-171) sluit die volgende in: Daar is dikwels 'n eensydige klem op oorwinning (deur die Gees) en 'n onderbeklemtoning van die kruis, redding en heiligmaking; die vraag of worship werklik tot gevolg het dat God sy mense hoor soos Wimber beweer; die vraag of CA werklik spontaan is indien dit op 'n vaste skema (Wimber se vyffasemodel) gebaseer is; die vraag of CA op 'n pneumatologiese Christologie of 'n Christologiese Pneumatologie rus; die vraag of CA werklik tot' $n$ meer intieme lewe met God lei as die ander benaderings tot musiek; die vraag waarom die nagmaal binne die CAbeweging verwaarloos word; die verwaarlosing van die persoon en werk van Jesus Christus in CA. Vanuit die ander benaderings tot aanbidding word op 'n positiewe noot ook opgemerk dat daar binne die CA 'n dimensie teenwoordig is wat dikwels binne die ander benaderings afwesig en selfs gemis word.

\section{Gemengde aanbidding (Blended worship)}

Webber (2004:175-191) beskryf blended worship [gemengde aanbidding ${ }^{7}$ ] (GA) as 'n sintese tussen die Liturgiese Vernuwingsbeweging (sestiger- en sewentigerjare) aan die een kant en die Kontemporêre Vernuwingsbeweging aan die ander kant. Die Liturgiese Vernuwingsbeweging van die twintigste eeu sluit volgens Webber (2004:176) verskeie tradisies in, naamlik die Liturgiese, Gereformeerde, Anabaptiste, Restorasie (Restoration), Herlewing (Revivalist), Kwaker, Heiligheid en Afro-Amerikaanse tradisies. Die Liturgiese Vernuwingsbeweging het in ses groot bewegings in die erediens gekulmineer. Hierdie bewegings is: die herstel van die teologie van aanbidding, 'n nuwe waardering vir die historiese viervoudige struktuur van die erediens, 'n nuwe besinning oor die nagmaal, die herstel van die Christelike jaar, nuwe vrae oor die rol en plek van musiek asook ander kuns binne die erediens, en nuwe pogings om die deelname van die gemeente te vergroot.

Binne die Kontemporêre Hernuwingsbeweging onderskei Webber (2004:177-178) die invloed van die Pentekostalistiese beweging, die Latter Rain Movement en die opkoms van die 'chorus tradition' onder invloed van Bill en Gloria Gaither. Webber sien die GA-beweging as die uitkoms van 'n strategiese beplanning tussen homself en Chuck Fromm, Hoof uitvoerende beampte van Maranatha, in 1987 om hierdie twee bewegings (die Liturgiese Vernuwingsbeweging en die Kontemporêre Vernuwingsbeweging) met mekaar te versoen en te kombineer.

7.Webber (2004:179) gebruik tereg die woord "converging' in hierdie verband Blended worship word daarom ook dikwels konvergensie-liturgie genoem (vgl. Blended worship word daarom ook dikwels konvergensie-liturgie genoem (vgl.
Van der Merwe 2009b:167. Ter wille van duidelikheid word hier met gemengde aanbidding $(\mathrm{GA})$ volstaan. 
In hierdie sin is GA dus die konvergensie van die ses groot bewegings van die Liturgiese Vernuwingsbeweging met die Kontemporêre Beweging se soeke na die werking van die Heilige Gees en 'n outentieke ervaring van God. GA vind uitdrukking in drie tale, te wete die taal van misterie (t.o.v. God die Vader), die taal van storie (t.o.v. Jesus Christus) en die taal van simbool (t.o.v. die Heilige Gees). Hierdie indeling lei tot baie kritiek vanuit ander bewegings. GA gaan uit van die viervoudige struktuur van die erediens, naamlik die versameling, die Woord, die Tafel, en die uitstuur). Musiek uit verskeie bronne en tradisies, maar eie aan die kultuur en demografie word binne hierdie liturgiese struktuur gebruik en streef na maksimum deelname van die deelnemers. Twee belangrike bybelse beginsels is die deelname van die gemeente en die vryheid van die kunstenaars om die evangelie in kunsvorms uit te druk. In kort is GA die gemeente se diens en aanbidding en nie 'n vertoning nie. 'n GA-erediens sal dus musiek uit verskeie tradisies bevat, byvoorbeeld 'Holy, holy, holy' (Sanctus), liedere uit die ryk verskeidenheid hymns, chorusses asook kontemporêre musiek. Die klem val deurentyd nie op die aanbiddingstyl nie, maar op die inhoud en die kultuur waar die aanbidding plaasvind.

Kritiek vanuit die ander vyf bewegings tot hierdie erediens sluit die volgende in (Basden 2004:192-213): die GA-beweging vertoon 'n Euro-Amerikaanse karakter wat dalk minder effektief in 'n Afrika-kultuur kan wees; die GA-beweging is steeds baie nou aan tradisie en veral die Liturgiese Benadering verbonde; die GA-beweging bou hoofsaaklik op die viervoudige struktuur van aanbidding - laasgenoemde is primêr 'n Ou-Testamentiese aanbiddingstruktuur (Eks 24:1-11) en nie soseer 'n Nuwe-Testamentiese struktuur nie en dit word binne die GA-beweging baie wetmaties hanteer; GA neem nie die verskillende generasies genoegsaam in ag nie.

\section{Opkomende of ontluikende aanbidding (Emerging worship)}

Morgenthaler (2004:217-230) beskryf Emerging Worship (ontluikende aanbidding; OA) as 'n poging om ' $n$ heilige ruimte (sacred space) in 'n posthumanistiese wêreld te skep. Binne hierdie ruimte word baie erns met die gebrokenheid gemaak wat eie is aan die selfbewussyn van die postmoderne mens. Binne die gebrokenheid word OA as 'n herbelyning (realignment) beskryf waar substansie baie belangriker as styl is. OA poog om die aanbidder in kontak met die persoon en voortgaande werk van God deur Jesus Christus te bring; laasgenoemde is nie noodwendig die bewuste behoefte van die aanbidder nie. OA kan dus 'n wye verskeidenheid elemente insluit soos drama, video, nuwe aanbieding van ou liedere (hymns), mimiek, gebed, refleksie, sketse, geloofsbelydenis, graffiti, kunswerke, en nog meer (Morgenthaler 2004:224). OA word gekenmerk deur 'the almost wholesale rejection of anything older than we are' (Morgenthaler 2004:225). Binne die OA-erediens, met groot klem op rekontekstualisering en 'n vermyding van enige vorm van prototipes, speel gemeentesang 'n baie klein rol. Morgenthaler (2004:229) beskryf dit as

... an escape from worship as music (most often, whatever the worship-music industry is dictating this month) to worship as a whole-person, indegenous encounter with God: visual, aural, tactile, kinetic, emotional, and cerebral.

Kritiek teen die OA-beweging (vanuit die ander vyf benaderings) sluit onder andere die volgende in (Basden 2004:231-250): die gevoel dat OA te kontekstueel is en as 't ware in die konteks van die posthumanistiese mens opgaan; kritiek teen die vanwaar en die waarnatoe (m.a.w. wat ontwikkel dit en waarin?); die vraag of OA werklik iets nuuts is wat emerge en of dit net 'n graad van liturgiese aanbidding is wat reeds vir eeue daar is; die vraag of ons werklik kan praat van 'an exponentially diversifying culture' (Morgenthaler 2004:234); die vraag na die teologiese onderbou van die OA-beweging; die oordrewe 'artefactual ethos'; die vraag of dit werklik menslik moontlik en haalbaar is om elke week 'n radikaal nuwe liturgie te hê sonder om tog later in 'n vorm van herhaling te verval; die gevaar dat die Woord na die periferie verskuif; die vraag of dit wat as nuut aangebied word nie ook maar tydgebonde en passé is nie; en die vraag of liturgie en aanbidding nie in 'n sekere sin ook kontrakultureel moet wees nie.

\section{Invloed van die verskillende benaderings op die kerklied in die NG Kerk}

Basden (2004) se identifisering en veral die beskrywing van verskillende benaderings in die Noord-Amerikaanse kerkliedlandskap help 'n mens om soortgelyke stromings of benaderings op eie bodem raak te sien en beter te verstaan. Binne die Suid-Afrikaanse konteks sou ten minste 'n sewende benadering ook bygevoeg word, naamlik die Afrika-benadering en verskeie variasies daarvan, maar daar is waarskynlik baie meer benaderings. Dit verg geen inspanning om raak te sien dat al ses hierdie benaderings (of variasies daarvan) ook binne die Suid-Afrikaanse konteks van kerke en denominasies waarneembaar is nie; hier kan onder andere gedink word aan die Anglikaanse kerk (FLA), die Gereformeerde Kerke in Suid-Afrika (TLGA), die Nederduitsche Hervormde Kerk van Afrika (TLGA), nuwe onafhanklike (vrye) kerke asook individuele gemeentes uit verskeie hoofstroomkerke (KA en GA), die Charismatiese kerke (CA) en die Ontluikende kerke (OA) om slegs enkele voorbeelde in die algemeen te noem.

Die vraag is of hierdie stromings of bewegings ook binne die NG Kerk aan die begin van die een-en-twintigste eeu voorkom. Hoe lyk die landskap van kerksang in die NG Kerk in die tweede dekade van die derde millennium na Christus? Watter invloed het hierdie bewegings op die kerklied in die NG Kerk? Die vermoede is dat die invloed van die verskillende benaderings tot kerksang ' $n$ beduidende invloed op gemeentesang in die NG Kerk het en dat talle verskuiwings in die NG Kerk se liederelandskap in 'n mindere of meerdere mate aan die stromings in die breër kerkverband verbind kan word. 


\section{Tradisionele landskap van musiek in die NG Kerk}

Van der Merwe (2009b:250) som tereg op dat die NG Kerk vir baie jare soos 'n franchise gefunksioneer het. Gemeentes regoor Suid-Afrika het in terme van die liturgie dieselfde gelyk: dieselfde liturgie, dieselfde liturgiese drag en ook dieselfde liturgiese sang en repertorium van liedere. In al die NG-gemeentes regoor die land het die gemeentesang en -musiek naastenby soos volg gelyk: dit het op vaste plekke in die erediens voorgekom (lofsang, lied na die Wet, skuldbelydenis, lied na die geloofsbelydenis, toepassingslied; vgl. NGK 1988; 2010); die gemeente het (meesal staande) liedere uit die Psalms en Gesange (NGK 1978) gesing en later uit die Liedboek van die Kerk (NGK 2001). Die begeleiding is deur 'n orrelis op 'n kerkorrel verskaf. Die liggaamstaal tydens die sang was meestal tot sit en staan beperk met (na my mening) baie min waarneembare emosies tydens die sang. Later het die gebruik van voorsang inslag gevind en het gemeentes voor die aanvang van die erediens (wat amptelik met die votum begin het) 'n paar liedere sittende saamgesing. Hierdie liedere was dikwels in geen spesifieke volgorde nie en is in baie gevalle gesien as ' $n$ geleentheid tot die aanleer van nuwe liedere of die inoefening vir die erediens wat volg. Soms is dit egter ook gesien as 'n voorbereiding van die atmosfeer vir die erediens (vergelyk in hierdie verband die opmerkings van Strydom 1994:349).

Binne die beskrywing van die stromings in Noord-Amerika (Basden 2004) sou sang en musiek binne die NG Kerk daarom breedweg as 'traditional hymn-based worship' beskryf kon word. Binne hierdie benadering tot kerksang speel 'n vaste liturgiese orde, 'n vaste liedrepertorium in gedrukte vorm en die gesonge teks 'n groot rol (Best 2004:59-75). In die sentrum van die sang binne hierdie benadering staan die liedboeke (hymnbooks) van hoogstaande gehalte ten opsigte van die teks, musiek en style (vgl. Strydom 1983:185). Laasgenoemde sluit die strofiese liedvorms, kantillering, miniatuurvorms, kanons, wisselsangvorms, Singsprüche, Folkloristiese liedmateriaal, ensovoorts in (Strydom 1994:334). Binne die NG Kerk het die Psalms en Gesange (1978) en later die Liedboek van die Kerk (2001) hierdie funksie vervul. Gemeentekore was 'n algemene verskynsel en koorsang is dikwels gebruik om gemeentesang aan te vul en te versterk. Die orrel is prominent as begeleidingsinstrument binne hierdie benadering gebruik en dikwels is die wenslikheid of gepastheid van ander instrumente bevraagteken (vgl. Barnard 1981:29, 587-588; Strydom 1994:375).

\section{Landskap van kerkmusiek aan die begin van die een-en-twintigste eeu}

Die landskap van die kerklied (en die liturgie) in die NG Kerk het in die afgelope jare (25 jaar?) dramaties en ingrypend verander (Pieterse 2011:47; Wepener 2009:188-189). Calitz (2011:330-393) dui deur middel van 'n empiriese ondersoek in Potchefstroom aan hoe gemeentes van die NG Kerk se benaderings, style, repertoriums en aanbiedings toenemend van mekaar verskil. Die repertorium van die meeste NG-gemeentes in die studie is geensins meer tot die Liedboek van die Kerk (2001) beperk nie; hierdie verskynsel is wyd waarneembaar en nie tot die NG-gemeentes in Potchefstroom beperk nie. Wepener (2009:188-189) identifiseer eietydse tendense rondom die erediens en noem in hierdie verband onder andere 'n 'groter soeke en verlange na 'n ervaring van God se teenwoordigheid' en 'voortdurende vernuwing rakende musiekstyle en -smake'.

Daar is ook groot variasie ten opsigte van begeleiding, aanbieding, genres en style. 'n Repertorium wat liedere uit verskeie tradisies insluit, is in die meeste gemeentes van die NG Kerk waar te neem. Verskillende style, inkledings en repertoriums vind dikwels hulle neerslag in verskillende soorte eredienste soos kinderdienste, jeugdienste, jean-entekkiedienste, tradisionele dienste, gesinsdienste, en andere (vgl. ook die voorbeelde in Wepener 2009:182-189). Die repertorium van liedere sluit in baie gemeentes tans variasies of kombinasies van die volgende in:

- Liturgiese liedere soos die Sanctus.

- 'n Seleksie van hymns (en vertalings daarvan) uit die ryk verskeidenheid hymns, veral die Engelse en Amerikaanse hymns (bv. Omdat Hy leef, Ek weet verseker, Strome van seën van bowe, ens.).

- 'n Verskeidenheid liedere (opgeneem in die Liedboek van die kerk) afkomstig uit verskeie tydperke en vastelande; die Liedboek van die kerk bevat ook al die Psalms in berymde formaat.

- 'n Groeiende aantal nuwe klassieke komposisies (ingesluit in die VONKK-versameling by www.vonkk.co.za).

- 'n Groeiende aantal kontemporêre liedere verwerk en opgeneem in die FLAM-versameling by (www.flam. co.za).

- 'n Groeiende aantal vrye liedere opgeneem uit die wye verskeidenheid liedere geadministreer deur die Christian Copyright Licensing International (CCLI) (www.ccli. co.za).

- Enkele vrye liedere geskryf en soms getoonset in 'n plaaslike gemeente.

Instrumente wat tans vir begeleiding in die eredienste gebruik word, sluit onder andere die klassieke kerkorrel, tromme, klassieke kitare, elektriese kitare, baskitare, tamboeryne, klaviere, keybords, trompette, harpe, fluite en saksofone in. Die gebruik van die gedrukte liedbundel word toenemend deur die gebruik van dataprojektors en digitale skerms vervang. Kerkgeboue word al hoe beter toegerus met goeie klankstelsels vir meer effektiewe klankversterking. Musiekgroepe en begeleidingsgroepe het 'n algemene verskynsel geword en dikwels word die koor en voorsanger(s) deur laasgenoemde vervang. Terme soos worship leader (aanbiddingsleier), worship group (musiekgroep, orkes en lof-en-aanbiddingsgroep), worship team, stage, en praise and worship het algemene terme in baie NG-gemeentes geword. Die itemmatige aanbieding (marching orders - Wolterstorff 1992:273) het vir 'n toenemende en eietydse free-flow plek gemaak (vgl. Barnard 2006:81). In baie gemeentes word 'n verskeidenheid liedere, instrumente, genres en style naas mekaar gebruik; dikwels 
word lukraak na kontemporêre of blended worship verwys. In ander gemeentes word verskillende eredienste aangebied om vir verskillende generasies, spiritualiteite en behoeftes voorsiening te maak. Hierdie beweging kan positief en negatief beoordeel word.

Gemeentesang word al hoe meer as praise en worship beskryf'n term afkomstig uit die kontemporêre en charismatiese beweging - vgl. Barnard 2006:80-81). Die pentekostalistiese en charismatiese invloed het hierin 'n groot rol gespeel (Strydom 1994:123-134; Barnard 2006:80). Sang en musiek is nie meer tot enkele liedere uit die amptelike liedbundel beperk wat op vaste plekke binne die liturgie funksioneer nie; eredienste word al hoe meer deur 'n lang lof- en aanbiddingsessie (praise and worship) aan die begin van die erediens gekenmerk met ' $n$ baie sterk belewenisdimensie, dikwels in 'n volgorde van lof na die aanbidding. Tydens hierdie lof-en-aanbiddingsessie word verskeie instrumente gebruik asook liedere uit verskeie tradisies en style - veral ook uit die kontemporêre en vrye korpus van musiek. Laasgenoemde sluit veral ook Engelse liedere in. Die lirieke word op 'n dataskerm geprojekteer met behulp van 'n dataprojektor en funksionele sagteware. 'n Nuwe konvergensie tussen beeld, klank en ritme is opvallend (Barnard 2006:87). Waarneembare liggaamstaal sluit dikwels sit, staan, handeklap, die ophef van hande, die sluit van oё, en geringe ritmiese bewegings in - laasgenoemde wissel van gemeente tot gemeente en erediens tot erediens. Janse van Rensburg (2004:57) beklemtoon tereg dat dergelike liggaamstaal nie sonder meer as ongereformeerd afgemaak kan word nie. Die toepassingslied na die verkondiging word uit 'n wye verskeidenheid bronne gekies wat nie tot die Liedboek van die kerk (NGK 2001) beperk is nie. Sang en musiek is uiters kontekstueel (Barnard 2006:88) en heg met die plaaslike en kontemporêre kultuur verbind (Calitz 2011:263). Alhoewel die musiek baie ooreenkomste met musiek uit die Pentekostalisiese en Charismatiese tradisies vertoon, ontbreek die sterk (oordrewe?) klem op die gawes en die werk van die Gees uit laasgenoemde tradisies.

Die verandering in die landskap van die kerklied is egter nie tot bogenoemde beperk nie, aangesien die beweging nie net in een rigting plaasvind nie. Buiten die beweging wat hierbo beskryf word (van 'traditional hymn-based' na kontemporêr), is daar ook in baie gemeentes ' $n$ beweging in die rigting van die formeel-liturgiese musiek en liturgie (Basden 2004) met 'n nog groter klem op die vaste liturgiese orde, die gedrukte liedbundel en elemente (responsoriese gebede, belydenisse en sang) uit die liturgiese tradisie van die breër kerk. Musiek binne hierdie beweging is dikwels meer formeel en meditatief. Liedere word uit die lang en ryk geskiedenis van die kerk geleen. Die Liturgiese Beweging het ' $n$ groot rol in die herontdekking van die groot bewegings (momente) in die erediens gespeel, asook in die waarde van skatte uit die ryk liturgiese en himnologiese tradisie en geskiedenis van die kerk. Hierdie beweging sou in oorvereenvoudigde terme as ' $n$ beweging in die rigting van die formeel-liturgiese aanbidding (FLA) beskryf kon word (Zahl 2004). Verskeie variasies kan binne hierdie beweging waargeneem word.

Daar is ook 'n groot aantal gemeentes waar eredienste deur die vaste ordes soos aanbeveel in die Handboek van die Erediens (NGK 1988), die sing van liedere slegs afkomstig uit die amptelike Liedboek van die Kerk, orrelbegeleiding, en dergelike sake gekenmerk word. Binne Basden (2004) se onderskeiding sou dit aangedui kon word as 'traditional hymn-based singing' waar die amptelike lied in gedrukte vorm 'n groot rol speel. Ook hier is dit nie rigied nie, omdat die gedrukte bundel in baie gevalle digitaal geprojekteer word.

Myns insiens kan hierdie drie bewegings uitgesonder word as die drie groot bewegings of stromings in kerksang en musiek binne die NG Kerk aan die begin van die een-en-twintigste eeu: 'n beweging in die rigting van die kontemporêre en die formeel-liturgiese musiek met 'n (hernude) keuse vir die 'traditional hymn-based'-benadering. Binne hierdie drie bewegings is ' $n$ magdom variasies en kombinasies waarneembaar en sou daar dikwels ook sprake wees van kleiner of groter variasies van bricolage (Calitz 2011:389). Binne elkeen van hierdie bewegings is daar bepaalde sterk en swak punte.

\section{Voorbeelde van bewegings binne die NG Kerk}

Die verandering in die landskap van die kerklied binne die NG Kerk kan kortliks met enkele voorbeelde geilllustreer word:

- Die Suiderkruis Gemeente (Potchefstroom) het op 21 April 2013 tydens 'n gewone oggenddiens in die kerkgebou die volgende liturgiese orde gebruik: 'n openingsgebed waarna die lofsang begin het met 'n oproep tot lof deur die lied, Kom sing 'n nuwe lied (vrye lied), gevolg deur 'n lofkeurspel (Hosanna, Kom loofdie Heer en Die Heremy God)almal vrye liedere buite die amptelike liedbundel. Die keurspel is opgevolg deur Vreugde, vreugde ('n vertaling van die Engelse lied, Joyful, joyful wat opgeneem is in die nuwe VONKK-bundel). Die lof het met 'n kinderlied (Ek is bly ek ken vir Jesus) uit die amptelike liedbundel (voorheen 'n vrye lied, maar opgeneem in die Liedboek van die Kerk 2001) afgesluit. Die lofsangsessie is deur 'n aanbiddingsessie opgevolg wat drie liedere ingesluit het: U liefdeslied vir my (kontemporêre lied opgeneem in die FLAM-versameling), Koning van my hart (kontemporêre lied uit die Charismatiese kerke, opgeneem in die FLAMversameling) en Jesus, groot bo almal ('n vertaling van die Engelse lied, Jesus, name above all names - aanvanklik opgeneem in Jeugsangbundel I en daarna gedeeltelik opgeneem in die Liedboek van die Kerk 2001). In aansluiting by die preek is Douglas Elzroth se lied, Abba to me, as 'n luisterlied gebruik. Die toepassingslied was Sy Naam is Jahwe (vrye lied, nie opgeneem in die amptelike liedbundel of een van die nuwe liedversamelings nie). Die begeleiding is deur ' $n$ musiekbedieningsgroep met instrumente (klawerbord, twee kitare, tromme, baskitaar, trompet en tamboeryn) gedoen. Vier lede van die musiekgroep het met mikrofone voorgesing. 
Die volgende waarnemings kan met betrekking tot hierdie diens gemaak word:

- Die liturgiese orde is 'n variasie op die voorgestelde liturgiese ordes vir die oggenddiens soos weergegee in die Handleiding vir die Erediens (NGK 2010) en dit sluit drie van die vier bewegings in die erediens in, naamlik die toetrede, die Woorddiens en die uitsending.

- 'n Totaal van 10 liedere is tydens die erediens gesing waarvan slegs twee liedere uit die amptelike liedbundel van die NG Kerk afkomstig is. Die oorblywende liedere sou beskryf kon word as kontemporêre liedere en liedere uit die wye versameling hymns.

- Die begeleiding is nie deur die kerkorrel gedoen nie, maar deur 'n verskeidenheid ander instrumente.

- Die lirieke is met behulp van 'n dataprojektor vertoon. Die gedrukte liedbundel is glad nie tydens die erediens gebruik nie.

- Die sang tydens die erediens sou dus nie by die beskrywing van 'traditional hymn-singing' soos wat dit vir baie jare beskryf kon word, inpas nie, maar eerder as 'n unieke kombinasie van 'traditional hymn-based' met kontemporêre musiek - dus 'n vorm van GA. Dit sou ook baie moeilik as slegs kontemporêr beskryf kon word.

- Die NG-gemeente Rant-en-Dal in Krugersdorp aan die Wesrand het op 14 April 2013 tydens 'n oggenddiens in die hoofgebou die volgende liturgie gebruik: mondelinge afkondigings en terugvoer oor finansies is voor die aanvang van die erediens gedoen. Die erediens is met 'n votum en seëngroet ingelei waarna die gemeente die (Apostoliese) geloofsbelydenis hardop saam gesê het. Die gemeente het in lofsang gevolg deur die volgende liedere te sing: Wie regeer (kontemporêre Afrikaanse lied, geskryf deur Juanita du Plessis), gevolg deur Sing Halleluja (kontemporêre lied, geskryf deur Romanz) en Lank genoeg (kontemporêre lied, geskryf deur die groep Onbeskaamd). Na afloop van die lof is die sakrament van die doop bedien waar die liturg ' $n$ lied gesing het wat hy self vir die geleentheid geskryf het. Na die gelukwensing is die Skriflesing uit Efesiërs 1 gedoen en die liturg se preek het daarna gehandel oor die tema: Jy is geroep vir groot dinge. Die verkondiging is deur die openbare gebed opgevolg, waarna In die hemel is die Heer (kontemporêre lied, opgeneem in FLAM) as die slotlied of toepassingslied gesing is. $\mathrm{Na}$ die seënbede was daar geleentheid vir gesellige saamwees (koinonia). Die begeleiding tydens die erediens is deur ' $n$ orkes gedoen wat uit tromme, 'n klavier, sintetiseerder, 'n baskitaar, twee akoestiese kitare, 'n elektriese kitaar, perkussie en sangers saamgestel is.

Uit die bondige beskrywing van die liturgie kan enkele observasies gemaak word:

- Die liturgiese orde is 'n variasie op die voorgestelde liturgiese ordes vir die oggenddiens soos weergegee in die Handleiding vir die erediens (NGK 2010) en sluit drie van die vier bewegings in die erediens in, naamlik die toetrede, die Woorddiens en die uitsending.
- Die liedere tydens die erediens is uit ander bronne as die amptelike liedbundel van die NG Kerk afkomstig. Nie een van die liedere wat tydens die erediens gesing is, kom uit die amptelike liedbundel van die kerk nie. Die liedere kan oorwegend as kontemporêr beskryf word.

- Die begeleiding is nie met die kerkorrel gedoen nie, maar met behulp van ' $n$ verskeidenheid ander instrumente.

- Die lirieke is met behulp van 'n dataprojektor vertoon. Die gedrukte liedbundel is glad nie tydens die erediens gebruik nie.

- Een lied is deur die liturg self vir gebruik by die spesifieke geleentheid gekomponeer (vgl. Calitz 2011:372-373).

- Die sang tydens die erediens sou dus nie by die beskrywing van 'traditional hymn-singing' (soos wat dit vir baie jare beskryf kon word) inpas nie, maar eerder as 'n variasie op die kontemporêre benadering.

- Die NG-gemeente Constantiakruin hou Sondae ses verskillende eredienste - elkeen met 'n unieke aanslag. Die Insync-erediens in die aand word as 'n buite-die-bokserediens vir jongmense met 'n upbeat- karakter beskryf. Die erediens op 14 April 2013 het soos volg verloop: Die orkes het met 'n opener-lied, Nothing is impossible, begin. Dit het die mense kans gegee om in te stap (daar word baie buite op die gras voor die aanvang van die erediens gesosialiseer). Na die opener het die liturg die gehoor verwelkom, 'n aantal afkondigings gemaak, waarna die kollekte opgeneem is. Alles het in 'n gemaklike kuierstyl geskied. Die liturg het die afkondigings met 'n gebed afgesluit. Die orkes het met 'n lof-en-aanbiddingstyd van ongeveer 25 minute voortgegaan waartydens die volgende liedere gesing is: King (kontemporêre lied van die groep Tree63), Mighty to save (kontemporêre lied deur Hillsong), en Hungry (kontemporêre lied). Na die liedere het die aanbiddingsleier kortliks 'n getuienis met die gemeente gedeel en voorgegaan in gebed. Daarna het die gemeente Heart of worship (kontemporêre lied deur Matt Redman) gesing. Die prediker het by die aanbiddingsleier oorgeneem en 'n gebed gedoen. Hy het die tema, Supernatural, aan die orde gestel en gevra wie dit kyk. 'n Kort loksnitvideo uit die Supernatural TV-reeks is gespeel waarna die preek gevolg het met sterk visuele hulp van 'n Prezi (rekenaarsagteware vir die vertoon van interaktiewe skyfies op die skerm). Die visuele aanbieding het ongeveer 40 skyfies met baie prente en teksverse bevat. Een van die teksverse (1 Joh $4: 4)$ is verskeie kere hardop deur die gehoor herhaal. Die liturg het met 'n gebed wat ook 'n seënbede betrek het, afgesluit. Die mense het uitgestap terwyl 'n CD gespeel het. Die erediens is deur ' $n$ koinonia-geleentheid en 'n kuier na die tyd opgevolg.

Uit die kort beskrywing van die liturgie kan enkele observasies gemaak word:

- Alhoewel die liturgie 'n variasie op die voorgestelde orde (Handleiding vir die erediens 2010) vir die aanddiens is, verskil die inkleding daarvan radikaal van die tradisionele inkleding van die liturgie. Daarmee verskil die inkleding van die liturgie radikaal van die 'traditional hymn-based' 
tradisie (vgl. Best 2004:59-75), waar 'n vaste orde en die amptelike kerklied in gedrukte vorm 'n sentrale plek het.

- Die liedere in die erediens kan as kontemporêre liedere in 'n radikaal ander genre as die amptelike kerklied beskryf word; enkele liedere is uit die Charismatiese tradisie afkomstig. Die liedere is almal Engels en deur sangers in die kontemporêre musiekbedryf geskryf. Geen liedere uit die amptelike liedbundel is tydens die erediens gesing nie.

- Die begeleiding is deur ' $n$ band gedoen wat deur ' $n$ professionele en betaalde aanbiddingsleier (worship leader) gelei is. Die musiek is professioneel en van hoogstaande gehalte.

- Die erediens sou as 'n unieke kombinasie en variasie van verskeie stromings ten opsigte van kerksang binne die breë kerk beskryf kon word. Die mees prominente stromings wat hier waargeneem kan word, is die kontemporêre benadering en die Soeker-erediens.

- Die NG-gemeente Potchefstroom-Oos se oggenderediens op 20 Februarie 2014 het soos volg verloop: die gemeente het Lied 175 (uit Liedboek van die kerk) as introïtuslied gesing, waarna die liturg en die gemeente 'n reponsoriese votum gedoen het, gevolg deur 'n seëngroet uit Psalm 15 . Na 'n responsoriese skuldbelydenis het die gemeente verskeie liedere gesing, naamlik Lied 33, 147 en 146 uit die Liedboek van die Kerk en die Oorwinninglied (vrye lied). Die liturg het met die epiklesegebed gevolg, waarna die Skriflesing uit Matteus 5:1-12 gelees is, gevolg deur die Woordverkondiging. Na die slotgebed is die dankoffers opgeneem (met orrelspel tydens die opneem van die dankoffers). Die gemeente het Lied 530 as slotlied gesing. As deel van die uitsending is die lied, Gaan dan heen, gesing.

Die volgende observasies verdien vermelding:

- Die liturgie kom met die voorgestelde liturgieë in die Handleiding vir die erediens (NGK 2010) ooreen. Drie van die vier groot momente is teenwoordig: versameling, Woorddiens en wegsending.

- $\mathrm{Al}$ die liedere in die erediens is uit die Liedboek van die kerk (NGK 2001) afkomstig, met die uitsondering van twee liedere. Die Oorwinningslied is 'n eietydse lied met Afrikaanse woorde geskryf deur die gospelsanger Piet Smit op die melodie van The Battle Hymn of the Republic. Die wegsendingslied aan die einde is 'n eietydse lied geskryf deur Ellison Mouton (1997).

- Die begeleiding is deur ' $n$ professionele orrelis gedoen. Die woorde van die liedere is deur middel van 'n dataprojektor op 'n skerm vertoon.

- Die erediens sou in terme van Basden se werk (2004) as 'n kombinasie van die TLGA en FLA beskryf kon word. As gevolg van die gebruik van liedere buite die amptelike bundel sou hier ook sprake kon wees van 'n vorm van GA.

\section{'n Unieke vorm van 'blended worship'?}

In die meeste gemeentes is een of ander kombinasie van musiek uit die verskillende tradisies waarneembaar (vgl.
Calitz 2011:367-372). Laasgenoemde word dikwels lukraak as blended worship beskryf.

Webber (2004:175-190; cf. Van der Merwe 2009a:167; 2009b:252) merk tereg op dat die term blended worship allerlei negatiewe konnotasies saamdra en dikwels impliseer dat verskillende soorte liedere en begeleiding in een erediens saamgebring word. Hierteenoor beklemtoon hy dat blended worship nie slegs die byeenbring van verskeie liedere uit verskillende tradisies impliseer nie, maar dit is ' $n$ omvattende benadering wat nie net die musiek nie, maar ook alle ander liturgiese elemente insluit. Van der Merwe (2009a:169) gebruik in hierdie verband die term konvergensieliturgie en beklemtoon dat laasgenoemde op die 'heilige oortuiging dat ons die oue en die nuwe nodig het om gemeenskap te beoefen met gelowiges oor die hele wêreld en van alle tye' bou. Hierin speel die ses bewegings van die Liturgiese Vernuwingsbeweging 'n groot rol. By implikasie word die genres asook die repertorium van die musiek dan deur die teks van die dag asook die seisoen van die kerklike jaar bepaal. Binne hierdie breër definisie van blended worship sou die beweging in baie gemeentes dus baie moeilik as blended worship of konvergensiemusiek beskryf kon word. Waar 'n verskeidenheid musieksoorte in 'n noue verbintenis tot die ses bewegings van die Liturgiese Beweging aangewend word, sou tereg van blended worship (Basden 2004) of konvergensieliturgie (Van der Merwe 2009a:166) gepraat kon word. In baie gemeentes funksioneer die repertorium van musiek los van die ses bewegings van die Liturgiese Vernuwingsbeweging en sou die term blended worship (Basden 2004) nie toepaslik wees nie. Laasgenoemde veronderstel 'n ander vorm van blended worship as wat deur Webber (2004) aangedui word - dus 'n unieke of andersoortige konvergensie van musiek. Die huidige situasie binne gemeentes van die NG Kerk laat eerder die indruk van 'n beweging weg van TLGA na FLA, KA en OA toe. Die gestalte wat blended worship dan in gemeentes kry, is egter verskillend en word in die verhouding (gebruik) van die amptelike kerklied teenoor die verskillende vorms van die vrye lied (vgl. Calitz 2011:389) uitgedruk.

Die slotsom is egter steeds dat die toenemende sentrale fokuspunt nie die NG Kerk se tradisie rondom sang en musiek is nie en ook nie die gereformeerde afkoms van die lied nie, maar die 'Sache Jesu' (Heitink 2007:121-148).

\section{Die pad vorentoe}

Die kerk en meer spesifiek die NG Kerk leef in 'n nuwe era wat nuwe uitdagings aan die kerk stel (Niemandt 2007:9-34). Heitink (2007; vgl. ook Dreyer 2009) illustreer aan die hand van statistieke in Nederland dat die Protestante Kerke in Nederland in 'n groot krisis verkeer as gevolg van die dalende lidmaatgetalle van die verskillende protestante denominasies en gemeentes. Dreyer (2003:1050) wys daarop dat dieselfde tendens hom in die tradisionele Afrikaanse kerke in SuidAfrika afspeel; laasgenoemde sluit die NG Kerk in. Heitink (2007:2) konkludeer dat die kerk in 'n Kairos-oomblik leef en dat dit tyd is vir heroriëntasie (ibid:356). Laasgenoemde word 
deur talle plaaslike publikasies oor die kerk in Suid-Afrika bevestig (cf. Van Wyk \& Van der Walt 2000:65-77).

Die heroriëntasie waarna Heitink verwys, is nie 'n eenvoudige saak nie. Heitink (2007) identifiseer agt faktore waaraan die kerk daadwerklik moet aandag gee; laasgenoemde illustreer hoe kompleks die heroriëntasie is. In wese kom Heitink se betoog op 'n nuwe klem op die 'Sache Jesu' neer (ibid:121-148). Hierdie artikel fokus slegs op een klein onderdeel van die heroriëntasieproses, naamlik heroriëntasie met betrekking tot die kerklied binne'n nuwe konteks wat nuwe eise stel. Heitink (2007) verwys in hierdie konteks na die eis van inkulturasie (teenoor akkulturasie) binne 'n oorwegend postmoderne en sekulêre kultuur. Hoondert (2009:80) meld dat 'n ander soort lied in die postmoderne kultuur (era) onvermybaar is. Hierdie artikel wil geensins voorgee dat die heroriëntasieproses tot 'n nuwe nadenke oor die kerklied beperk is nie, of dat die heroriëntasie ten opsigte van die kerklied in 'n enkele artikel behandel of afgehandel kan word nie. Hierdie artikel wil egter wel beklemtoon dat die teenswoordige wêreld nuwe en uitdagende eise aan die kerklied stel, en dat die kerklied noodwendig in 'n proses van groot veranderings beweeg. Die landskap is reeds besig om te skuif.

Uit die diskussie rondom Basden (2004) se boek is dit duidelik dat die kerklied tans deur verskeie stromings (benaderings) in die breër kerk beïnvloed word. Laasgenoemde is geen nuwe verskynsel nie. Olivier (2006) dui oortuigend aan dat die Afrikaner (wat hoofsaaklik lidmate van die drie Afrikaanse kerke as) nooit net deur Calvinisme beïnvloed was nie, maar dat talle ander invloede ' $n$ rol in die Afrikaner se godsdiensbelewenis gespeel het. Olivier (2006:1470) gebruik die metafoor van ' $n$ dam waarin talle riviere en strome saamgekom het - strome soos die Reformasie, die Tweede Reformasie, Piëtisme, Metodisme, Liberalisme, Calvinisme en die Charismatiese beweging. Hierdie strome het oor al die jare in die kerklied van die NG Kerk neerslag gevind in die vorm van die Kinderharp, die Halleluja-bundel, die verskillende Jeugsangbundels asook die FLAM-liedere van vandag. Hierdie liedere het dikwels die kerklied verryk en in balans gehou (Calitz 2011). Dikwels het hierdie liedere ' $n$ plek in gemeentesang gevind as gevolg van die soeke en verlange na 'n meer intieme belewenis; laasgenoemde is ' $n$ toenemende behoefte binne die NG Kerk (Wepener 2009:189) en nie noodwendig teenstrydig met gereformeerdheid nie (Janse van Rensburg 2004:61). Olivier se metafoor van die dam sou goedskiks ook in die huidige situasie gebruik kon word. Tans word die groot dam van die NG Kerk (TLGA) deur riviere uit FLA, KA, CA en OA gevoed. Of hierdie situasie eenvoudig as 'n konvergensie van verskillende musiekstromings, dit wil sê blended worship (GA) beskryf kan word, is te betwyfel. In baie gemeentes sou eerder van 'n wegbeweeg van TLGA na ander benaderings soos KA, CA en OA gepraat kon word. Indien die term blended worship wel gebruik word, moet beklemtoon word dat dit 'n ander vorm van blended worship is as wat die term blended worship aanvanklik beteken het.

Binne 'n global village of die proses van globalisering (Niemandt 2007:10) met die geweldige vinnige vloei van informasie en die grootskaalse en voortdurende blootstelling aan verskeie tradisies en stromings, sal bewegings in die groter kerk 'n besliste invloed op die persepsie, inhoud, vorm en inkleding van die kerklied binne die NG Kerk hê. Daarom kan 'n mens aanneem dat die verskeidenheid benaderings tot die kerklied noodwendig op verskillende wyses in die kerklied van die NG Kerk neerslag sal vind. Dat dit reeds gebeur, word deur die beskrywing hierbo bevestig. Die landskap van die kerklied in die NG Kerk in Suid-Afrika het reeds baie verander en is steeds besig om vinnig en radikaal te verander. In die lig van Heitink se beskrywing hierbo (met die klem op inkulturasie en die Sache Jesu) kan hierdie proses van verandering ook 'n positiewe uitkoms hê.

Daar is egter ook belangrike vrae wat in hierdie oorgangstye deur elke gemeente beantwoord moet word, naamlik wat 'n gemeente se sang- en musiekbediening motiveer om te verander of om dieselfde te bly. Morgenthaler (2004:132-134) waarsku tereg teen die verkeerde motiewe (verveeldheid, pogings om tanende kerkbywoning te verbeter, finansiële oorwegings, en 'keeping up with the big churches next door') wat dikwels ten grondslag van gemeentes se musiekvernuwing lê. Sy wys tereg op die rol van kerkjaloesie (church envy) asook die streel van die leraars of leiers (ook musiekleiers) se eie ego. Dikwels word verandering in die musiekbediening deur persoonlike motiverings, of die leiers (lees ook musiekleiers) se eie loopbaanagendas gedryf. Dieselfde kan ook van kerkmusiek en kerkmusikante in 'n vorige bedeling gesê word. Binne die gereformeerde tradisie is voortgaande vernuwing imperatief, maar altyd gemotiveer deur die Solas van die Reformasie. Daarom moet alle vernuwing in sang en musiek altyd Skrifgetrou en Skrifgesentreerd wees. Laasgenoemde geld natuurlik nie net vir vernuwing nie; daar moet deurentyd gevra word of die huidige (of tradisionele) praktyk steeds Skrifgetrou en Skrifgesentreerd is. In elke era moet die kerk (plaaslike gemeentes) kan rekenskap gee of haar musiek die volle evangelie so effektief as moontlik aan die mense van haar tyd bemiddel. Janse van Rensburg (2004:64) som tereg op dat ons 'met vooropgestelde clichés sal moet klaarspeel en aan die hand van teologiese beginsels na liturgiese vernuwing moet streef wat met 'n gereformeerde teologie en spiritualiteit korrespondeer en tog kontemporêr en kontekstueel kan wees'.

Die NG Kerk kan egter nie ontsnap van die tyd waarin ons leef en die invloed wat dit op die kerklied uitoefen nie. Hoondert (2009) meld dat die opneem van 'n ander lied in die liedboek onvermydelik is. Binne ' $n$ liturgiese konteks waar bricolage aan die orde van die dag is, kan gemeentes nie die gevolge van bricolage ontsnap nie. Morgenthaler (2004:212) verwys na 'pastiche' ('n term uit die populêre kultuur en skone kuns) en verduidelik dit as 'pasting elements of meaning together in new forms'. Die landskap van die gereformeerde kerklied het reeds dramaties verander; hierdie proses is nog lank nie verby nie. Binne die liturgiese studie en meer spesifiek Himnologie kan hierdie verskuiwings nie langer geïgnoreer of ontken word nie. 


\section{Erkenning \\ Mededingende belange}

Die outeur verklaar dat hy geen finansiële of persoonlike verbintenis het met enige party wat hom nadelig of voordelig kon beïnvloed het in die skryf van hierdie artikel nie.

\section{Literatuurverwysings}

Barnard, A.C., 1081, Die erediens, NG-Kerkboekhandel, Pretoria.

Barnard, M., 2006, 'The Praise and Worship Movement and its relation to culture - an exploration of new fields of research in Liturgical Studies', Jaarboek voor LiturgieOnderzoek 22, 79-88.

Barnard, M., 2008, 'Bricolageliturgie: Liturgical studies revisited', Verbum et Ecclesia 29(1), 14-31. http://dx.doi.org/10.4102/ve.v29i1.2

Basden, P.A. (ed.), 2004, Exploring the worship spectrum, Zondervan, Grand Rapids.

Best, H., 2004, 'Traditional hymn-based worship', in P.A. Basden (ed.), Exploring the worship spectrum, pp. 59-75, Zondervan, Grand Rapids.

Calitz, C.J., 2011, 'The free song (hymn) as a means of expression of the spirituality of the local congregation with specific focus on the situation of the Dutch Reformed Church in South Africa', Doctoral Thesis, Faculty of Theology, University of Pretoria.

Christian Copyright Licensing International (CCLI), s.a., viewed 15 April 2014, from www.ccli.co.za

Dreyer, T.F.J., 2003, 'Statistieke vertel 'n storie - 'n Visie vir die Hervormde Kerk op pad na 2010', HTS Teologiese Studies/Theological Studies 59(4), 1045-1062. http://dx.doi.org/10.4102/hts.v59i4.685

Dreyer, T.F.J., 2009, "n Kerk met karakter: Die perspektief van Gerben Heitink', HTS Teologiese Studies/Theological Studies 65(1), Art. \#315, 5 pages.

Du Toit, J.H.H. (red.), 1983, 'n Geskiedenis van die Afrikaanse protestantse kerklied, NG Kerkboekhandel, Pretoria.

FLAM, s.a., ADGO se projekspan vir musiek, besigtig 15 April 2014, by http://www. flam.co.za

Heitink, G., 2007, Een kerk met karakter: Tijd voor heroriëntatie, Kok, Kampen.

Hoondert, M.J.M., 2009, 'Het liedboek of een liedboek: Over liturgisch-muzikaal bricoleren in de context van transformerende religiositeit', Jaarboek voor liturgieonderzoek 25, 71-85.

Horness, J., 2004, 'Contemporary music-driven worship', in P.A. Basden (ed.), Exploring the worship spectrum, pp. 99-116, Zondervan, Grand Rapids.

Janse van Rensburg, J., 2004, 'Wat is 'n Gereformeerde liturgie?', Acta Theologica 2(2), 45-65.
Long, T.G., 2001, Beyond the worship wars: Building vital and faithful worship, The Alban Institute, Durham.

Morgenthaler, S., 2004, 'An emerging worship response', in P.A. Basden (ed.), Exploring the worship spectrum, pp. 131-230, Zondervan, Grand Rapids.

Nederduitse Gereformeerde Kerk, 1976, Psalms \& gesange, NG Kerk-Uitgewers, Kaapstad.

Nederduitse Gereformeerde Kerk, 1988, Handboek vir die erediens, NG KerkUitgewers, Kaapstad.

Nederduitse Gereformeerde Kerk, 2001, Liedboek van die kerk, NG Kerk-Uitgewers, Kaapstad.

Nederduitse Gereformeerde Kerk, 2010, Handleiding vir die erediens, Bybel-Media, Wellington.

NGK kyk Nederduitse Gereformeerde Kerk.

Niemandt, N., 2007, Nuwe drome vir nuwe werklikhede, Lux Verbi.BM., Wellington.

Oliver, E., 2006, 'Afrikaner spirituality: A complex mixture', HTS 62(4), 1469-1487.

Pieterse, H., 2011, 'Die reformatoriese kerklike landskap', in C. Vos \& D. Human, Vaste Rots op wie ek bou, bl. 37-52, Lux Verbi, Kaapstad.

Strydom, W.M.L., 1983, 'Die himnologiese betekenis van die 1978-gesangebundel', in J.H.H. du Toit (red.), ' $n$ Geskiedenis van die Afrikaanse Protestantse kerklied, bl. 179-194, NG Kerkboekhandel, Pretoria.

Strydom, W.M.L., 1994, Sing nuwe sange, nuutgebore, NG Sendingpers, Bloemfontein

Van der Merwe, I.J., 2009a, 'Ontdek die bewegings in die erediens', in C.J. Wepener $\&$ I.J. van der Merwe (reds.), Ontdekkings in die erediens, bl. 165-180, LuxVerbi. $\mathrm{BM}$, Wellington.

Van der Merwe, I.J., 2009b, 'Tien hedendaagse liturgiese skuiwe', in C.J. Wepener \& I.J. van der Merwe (reds.), Ontdekkings in die erediens, bl. 250-253, LuxVerbi.BM, Wellington.

Van Wyk, A. \& Van der Walt, B., 2000, 'Sing vir die Here 'n nuwe lied', in E. Botha (red.), Venster op die Kerk, bl. 65-77, PU vir CHO, Potchefstroom.

VONKK, s.a., ADGO se projekspan vir musiek, besigtig 15 April 2014, by http://www. vonkk.co.za

Webber, R., 2004, 'Blended worship', in P.A. Basden, Exploring the worship spectrum, pp. 175-191, Sondervan, Grand Rapids.

Wepener, C.J., 2009, 'Ontdek eietydse tendense en uitdagings rondom die erediens', in C.J. Wepener \& I.J. van der Merwe (reds.), Ontdekkings in die erediens, bl. 181-194, LuxVerbi.BM., Wellington.

Williams, D., 2004, 'Charismatic worship', in P.A. Basden, Exploring the worship spectrum, pp. 139-152, Zondervan, Grand Rapids.

Wolterstorff, N., 1992, 'The reformed liturgy', in D.K. Mc Kim (ed.), Major themes in the reformed tradition, pp. 273-303, Eerdmans, Grand Rapids.

Zahl, P.F.M., 2004, 'Formal-liturgical worship', in P.A. Basden, Exploring the worship spectrum, pp. 23-26, Zondervan, Grand Rapids. 